\title{
Corporate Governance in Emerging Markets
}

\author{
Mariana Pargendler* \\ Oxford Handbook of Corporate Law and Governance \\ Jeffrey N. Gordon \& Wolf-Georg Ringe (Eds.) \\ Forthcoming
}

* Professor of Law, Fundação Getulio Vargas School of Law at São Paulo (Direito GV); Global Associate Professor of Law, New York University School of Law.

The author is grateful to Luca Enriques, Merritt Fox, George Georgiev, Jed Kroncke, Bruno Salama, Erik Vermeulen, and Chuck Whitehead for helpful comments on an earlier version of this paper. This paper is a work in progress and is forthcoming in the Oxford Handbook of Corporate Law and Governance (Jeffrey N. Gordon \& Wolf-Georg Ringe eds.). 


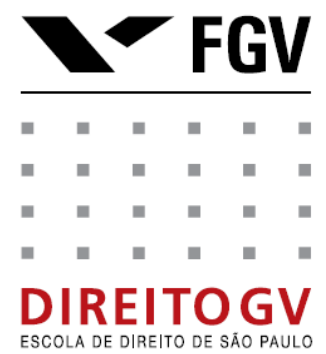

São Paulo Law School of Fundação Getulio Vargas - DIREITO GV

Research Paper Series - Legal Studies

Paper n. 100

Corporate Governance in Emerging Markets

Mariana Pargendler ${ }^{\alpha}$

São Paulo Law School of Fundação Getulio Vargas - DIREITO GV

June 2014

This paper can be downloaded without charge from DIREITO GV Working Papers at:

http://direitogv.fgv.br/publicacoes/working-papers and at the Social Science Research Network (SSRN) electronic library at: http://www.ssrn.com/link/Direito-GV-LEG.html.

Please do not quote without author's permission

${ }^{\alpha}$ Professor of Law. 


\section{Introduction}

The corporate governance movement, as well as the vast literature and industry to which it gave rise, is predicated on the premise that the structure, practices, and balance of power within the corporation matter for economic outcomes. The movement as we know it today first emerged in the United States in the late 1970s and early 1980s - a context of economic malaise and fear of imminent decline in view of the then booming economic performance of Germany and Japan. ${ }^{1}$ In an era marked by growing skepticism of government intervention, the cure for economic woes had to lie in the private sector. The New York Stock Exchange's pioneering move in attributing a monitoring role to the board by requiring audit committees to be composed of outside directors was a first step in this direction. ${ }^{2}$ Subsequently, the far more active role of private shareholders as corporate monitors in Germany and Japan would provide an attractive model for the revitalization and increased competitiveness of U.S. firms. ${ }^{3}$

While comparisons between foreign models of corporate ownership and control have been a staple of the corporate governance movement since its early days, the first such studies centered on a handful of mature economies - most conspicuously the

\footnotetext{
${ }^{1}$ For a history of the corporate governance movement, see Brian R. Cheffins, The History of Corporate Governance, in OXFORD HANDBOOK OF CORPORATE GOVERnANCE (Mike Wright, Donald Siegel, Kevin Keasey and Igor Filatotchev eds., Oxford University Press, 2013).

2 Jeffrey N. Gordon, The Rise of Independent Directors in the United States, 1950-2005: Of Shareholder Value and Stock Market Prices, 59 STAN. L. REV. 1465, 1465 (2007).

${ }^{3}$ See, e.g., Louis Lowenstein \& Ira M. Millstein, The American Corporation and the Institutional Investor: Are There Lessons from Abroad? 1988 COLUM. BUS. L. REV. 739.
} 
United States, the United Kingdom, Germany, and Japan. It was not until the 1990s and 2000s that the focus expanded to cover a larger array of jurisdictions. A number of economic and political factors help explain why corporate governance in emerging markets became an increasingly prominent theme in business, academic, and policy circles alike.

First, the fall of the Berlin Wall and the spread of the Washington consensus reinforced the wave of privatizations around the globe, and especially in the state-heavy economies of the old Second and Third World. A new system of corporate governance and financing was needed to replace the existing one based on state ownership of enterprise. It soon became apparent that privatization alone was unlikely to produce the desired improvements in economic performance in the absence of accompanying legal reforms that ensured a well-functioning corporate governance regime. ${ }^{4}$

Second, the 1990s witnessed the publication of several academic studies pointing to the existence of a causal relationship between financial development and economic growth. ${ }^{5}$ Concurrently, a series of highly influential, albeit controversial, works on "law and finance" suggested that corporate governance institutions and practices - in particular, the level of legal investor protection afforded to minority shareholders - helped explain the variation in the ownership structures of business corporations and the level of financial development observed around the world. ${ }^{6}$ In a period where the ascent of institutional economics persuaded international development agencies such as the World Bank to shift their strategy from the financing of physical infrastructure to the financing of improvements in institutional infrastructure, promoting corporate governance reform in emerging markets became a top policy priority. ${ }^{7}$ This concern was only reinforced as commentators blamed the Asian financial crisis of the

\footnotetext{
4 See Bernard Black, Reinier Kraakman \& Anna Tarassova, Russian Privatization and Corporate Governance: What Went Wrong?, 52 STAN. L. REV. 1731-1808 (2000).

5 See, e.g., Robert G. King \& Ross Levine, Finance and Growth: Schumpeter Might Be Right, 108 QUARTERLY J. ECON. 717 (1993); Ross Levine \& Sara Zervos, Stock Markets, Banks, and Economic Growth, 88 AM. ECON. REV. 537 (1998); Raghuram G. Rajan \& Luigi Zingales, Financial Dependence and Growth, 88 AM. ECON. REV. 559 (1998).

${ }^{6}$ See, for a review of this voluminous literature, Rafael La Porta et al., The Economic Consequences of Legal Origins, 46 J. ECON. LIT. 285 (2008).

${ }^{7}$ The establishment of the Global Corporate Governance Forum in 1999, an organization co-founded by the World Bank and the Organization for Economic Co-operation and Development (OECD) to "[support] corporate governance reform in emerging markets and developing countries," illustrates this trend. See http://www.gcgf.org.
} 
late 1990s on subpar corporate governance practices. ${ }^{8}$ Corporate governance improvements in emerging markets thus became a main area of concern at both domestic and international levels as an integral part of a developmental agenda.

Third, the growing attention to corporate governance in emerging markets is also attributable to strictly financial considerations. The spread of globalization, international trade, and financial liberalization worldwide in the last decades dramatically amplified cross-border investments. In 2012, for the first time in history, developing countries absorbed the lion's share of global flows in foreign direct investment. ${ }^{9}$ Domestic equity markets in emerging economies have also flourished, with firms from non-OECD countries raising a staggering $60 \%$ of the world's total IPO proceeds between 2008 and 2012. ${ }^{10}$ In this context, foreign investors exploring emerging market opportunities had a keen interest both in better understanding their existing corporate governance structures and in ascertaining the extent to which the introduction of superior practices could boost firm value.

This is especially so given the increasing appreciation of the economic importance of the so-called "BRICs" - an acronym devised by Goldman Sachs in 2001 to designate the giant emerging markets of Brazil, Russia, India, and China. ${ }^{11}$ According to estimates by the U.N. Development Program, by 2020 the joint economic output of Brazil, India, and China alone is expected to exceed the combined production of the United States, Canada, France, Germany, Italy, and the United Kingdom. ${ }^{12}$ Growth rates in the BRICs significantly outperformed those of developed economies in the 2000s, and played a key role in sustaining global demand in the immediate aftermath of the 2008 financial crisis.

For all these reasons, there has been a noticeable increase in the number of country-level corporate governance studies in different emerging economies, ${ }^{13}$ even if

\footnotetext{
${ }^{8}$ Simon Johnson, Peter Boone, Alasdair Breach \& Eric Friedman, Corporate Governance in the Asian Financial Crisis, 58 J. FIN. ECON. 141-186 (2000).

${ }^{9}$ United Nations Conference on Trade and Development (UNCTAD), World Investment Report 2013, at iii (2013), http://unctad.org/en/publicationslibrary/wir2013 en.pdf.

${ }^{10}$ Mats Isaksson \& Serdar Çelik, Who Cares? Corporate Governance in Today's Equity Markets, OECD Corporate Governance Working Papers No. 8, at 12 (2013).

${ }^{11}$ For a critique of the concept, see Ruchir Sharma, Broken BRICS: Why the Rest Stopped Rising, 91 FOREIGN AFF. 2 (2012).

12 United Nations Development Programme, Human Development Report 2013, at iv (2013), http://www.undp.org/content/dam/india/docs/human-development/HDR/HDR2013-Report-English.pdf.

${ }_{13}$ See, for a review of this literature, Stijn Claessens \& B. Burcin Yurtoglu, Corporate Governance in Emerging Markets: A Survey, 15 EMERGING MKTS. REV. 1 (2013).
} 
they still lag far behind the immense literature covering developed countries. Nevertheless, devising a common framework to examine the state of corporate law and governance in emerging markets remains challenging, for the simple reason that these countries are a diverse bunch. The very label emerging markets was first crafted in the 1980s, not as a scholarly category, but simply as a marketing tool for a new index of foreign stocks - as a substitute for the then prevailing, but evidently unappealing, designation of "Third World" countries. Since then, the tag also came to encompass certain ex-communist economies of the Second World, hence rendering the group even more heterogeneous.

Yet the shared trait of underdevelopment is evidently insufficient as a signal of underlying commonalities. Emerging markets are arguably even more diverse than developed economies, even though the latter's corporate governance systems are seldom grouped and studied as a unitary category. Indeed, countries such as Brazil, Russia, India, China, South Korea, and Turkey - to list only a few prominent examples - have deeply diverse histories, political systems, legal regimes, and economic structures. It should therefore come as no surprise that their corporate governance practices, too, look significantly different. Consequently, most sweeping generalizations about corporate governance in emerging markets - even if illuminating at a high level of abstraction - are unlikely to provide an accurate depiction of individual countries' realities.

With this caveat in mind, the remainder of this Chapter explores some of the key characteristics shared by corporate governance systems in emerging markets, examines the degree of convergence to international standards in the recent past, and identifies promising avenues for future research. Although the exposition will concentrate on the BRICs - the giant countries that achieved notably high levels of economic growth in the 2000 s -, it will also incidentally address the experience of other emerging markets as appropriate. The analysis will focus, in particular, on the driving forces, extent, and contours of corporate governance change in the last decades.

Despite their differences, emerging market economies are all latecomers in terms of capital market development, at least in recent history. But if the "emergence" of their capital markets was once a prophecy, it has since turned into reality, especially for the BRICs. As depicted in Figure 1 below, their stock markets have experienced significant 
growth since the 1990s - and, along the way, they have also shown a tendency to rise and fall in tandem. Apart from the intrinsic interest in these systems, the examination of the changing structures of corporate governance in emerging markets helps illuminate the variety of institutional arrangements that make capitalism viable around the world.

\section{Ownership structures}

Most, if not all, emerging market economies operate in a taxing institutional environment that fails both to fully protect property rights and to expediently enforce commercial agreements. These institutional shortcomings, in turn, require different adaptations to the way of doing business. For instance, a lack of property rights protection may concentrate ownership in the hands of the state itself or of otherwise powerful cronies, hence discouraging investment by outsiders. Likewise, difficulties in obtaining timely and impartial court enforcement of commercial agreements may lead firms to rely on extracontractual commitment mechanisms - such as family relationships, or longstanding reputation - or resort to vertical integration. ${ }^{14}$

\section{A. Ownership concentration and business groups}

In contrast to the model of dispersed ownership of publicly-traded companies often observed in the United States and the United Kingdom, but similarly to the developed economies of continental Europe, emerging markets boast a system of mostly concentrated corporate ownership in the hands of wealthy families or the state. Accordingly, the average free float of listed companies in India and Russia does not exceed $35 \%$, compared to over $90 \%$ in the United States and the United Kingdom. ${ }^{15}$ The presence of a powerful controlling shareholder affords political influence and reputational bonding that compensates for a lack of formal property rights protection and contract enforcement. This, in turn, entails that the primary agency costs in listed firms concern the divergent interests of controlling shareholders and minority shareholders - and not of managers and dispersed shareholders, as is the case in the widely-held corporations that populate Anglo-Saxon markets.

\footnotetext{
${ }^{14}$ Ronald J. Gilson, Controlling Family Shareholders in Developing Countries: Anchoring Relational Exchange, 60 STAN. L. Rev. 663 (2007).

${ }^{15}$ Goldman Sachs, EM Equity in Two Decades: A Changing Landscape, Global Economics Paper No. 204, at 18 (2010).
} 
In addition, emerging markets tend to offer lower levels of legal protection to outside investors, a feature which, according to the large literature on "law and finance,"16 also encourages ownership concentration and stifles capital market development, for at least two reasons. First, where minority shareholders are not adequately protected, entrepreneurs will be unwilling to give away control for fear of subsequent expropriation. Second, dispersed ownership - if it were to emerge - would be inherently unstable, since a corporate raider would have much to gain by acquiring a controlling stake in the market so as to extract hefty private benefits to the detriment of vulnerable minority investors. ${ }^{17}$ Conversely, concentrated ownership can be selfperpetuating, as existing controlling shareholders will have every incentive to lobby against corporate reforms that enhance minority shareholder rights, hence decreasing their wealth and power. ${ }^{18}$

It is particularly common for controlling shareholders in emerging markets to exert uncontested control over the firm without holding a majority of the voting stock. This is made possible through the use of control enhancing devices that dissociate cashflow rights and voting rights - a strategy that induces large shareholders to monitor management, albeit at the risk of significantly increasing their incentives to extract private benefits of control to the detriment of minority investors. ${ }^{19}$ Brazil, for instance, had the world's largest incidence of dual-class firms - with voting shares held by mostly corporate insiders and nonvoting shares by outside investors - as well as the greatest average gap between cash flow and voting rights. ${ }^{20}$ In other jurisdictions, such as Chile and South Korea, corporate pyramids are the preferred method through which shareholders control the firm without holding a commensurate equity stake. ${ }^{21}$

\footnotetext{
${ }^{16}$ See supra note 6.

${ }^{17}$ See, e.g., Lucian Bebchuk \& Mark Roe, A Theory of Path Dependence in Corporate Ownership and Governance, 52 STAN. L. REV. 127 (1999).

${ }^{18} I d$.

${ }^{19}$ George G. Triantis, Lucian A. Bebchuk \& Reinier H. Kraakman, Stock Pyramids, Cross-Ownership, and Dual Class Equity: The Creation and Agency Costs of Separating Control from Cash Flow Rights, in CONCENTRATED CORPORATE OWNERSHIP (Randall Morck ed., 2000).

${ }^{20}$ Andre Carvalhal da Silva \& Avanidhar Subrahmanyam, Dual-Class Premium, Corporate Governance, and the Mandatory Bid Rule: Evidence from the Brazilian Stock Market, 13 J. CORP. FIN. 1, 4 (2007); Tatiana Nenova, Control Values and Changes, in Corporate Law in BRAZIL 2 (Sept. 25, 2001) (unpublished manuscript), available at http://papers.ssrn.com/sol3/papers.cfm? abstract_id=294064.

${ }^{21}$ Fernando Lefort, Business Groups in Chile, in OXFORD HANDBOOK OF BUSINESS GROUPS (Asli M. Colpan, Takashi Hikino \& James R. Lincoln eds., 2010); Kon-Sik Kim, The Role of Judges in Corporate Governance: The Korean Experience, in TRANSFORMING CORPORATE GOVERNANCE IN EAST ASIA, 122 (Hideki Kanda, Kon-Sik Kim \& Curtis J. Milhaupt eds., 2008).
} 
Controlling shareholders in emerging markets often control not a single corporation, but rather an entire group of formally independent firms. Business groups play such a pivotal role in different emerging market economies that commentators have questioned the use of the term corporate governance, suggesting that, in such an environment, the group, not the individual firm, is the proper unit of analysis. ${ }^{22}$ The economic implications of business groups, however, remain the subject of debate. While the pyramidal structures adopted by some groups can be particularly conducive to expropriation of minority investors, the literature suggests that, in allowing for vertical integration, internal capital markets, and relational contracting, business groups may serve as a valuable adaptation to a weak institutional environment. ${ }^{23}$ More recently, commentators have come to underscore the strategic advantages of emerging market business groups in promoting long-term performance, suggesting that their conglomerate structure provides a useful model for developed markets as well. ${ }^{24}$

But if business groups are pervasive in most emerging markets, their precise contours vary from context to context. Diversification across different industries is the norm in some countries, such as Chile and South Korea, but less common in others, most conspicuously China. ${ }^{25}$ Their recent trajectory following economic liberalization in the 1990s has not been uniform either. Business groups became ever more connected and centralized in "small-world" fashion in Mexico and Brazil during this period, but more decentralized and fragmented in South Korea. ${ }^{26}$

\section{B. State ownership and influence}

Even after the wave of privatizations in the 1980s and 1990s, state ownership remains alive and well in most emerging markets. All of the BRIC countries continue to exhibit high levels of state ownership. By 2011, companies under direct government control comprised $80 \%$ of the market capitalization in China, $60 \%$ in Russia, and $35 \%$

\footnotetext{
${ }^{22}$ Randall Morck, Finance and Governance in Developing Countries, NBER Working Paper 16870 (Mar. 2011).

${ }^{23}$ For a review of the economic literature on business groups, see Tarun Khanna \& Yishay Yafeh, Business Groups in Emerging Markets: Paragons or Parasytes?, 45 J. ECON. LIT. 331 (2007).

24 J. Ramachandran, K.S. Manikandan \& Anirvan Pant, Why Conglomerates Thrive (Outside the U.S.), HARV. BUS. REV., Dec. 2013.

${ }^{25}$ Khanna \& Yafeh, supra note 23, at 333; Li-Wen Lin \& Curtis J. Milhaupt, We Are the (National) Champions: Understanding the Mechanisms of State Capitalism in China, 65 STAN. L. REV. 697, 711 (2013).

26 JON BROOKFIELD ET AL., THE SMALl WORLD OF BUSINESS GROUPS: LiBERALIZATION AND NETWORK DYNAMICS (Bruce Kogut ed., 2012).
} 
in Brazil. ${ }^{27}$ In fact, the relevance of state ownership for the corporate governance debate has arguably increased in recent decades, as a number of former governmental divisions came to assume the corporate form.

China has famously pursued a strategy of "corporatization, not privatization," which resulted in the massive floating of minority stakes in its newly-created stock exchanges in the last two decades. ${ }^{28}$ Despite subsequent reforms decreasing the number of non-tradable shares held by the state and the increase in private sector activity, SOEs remain dominant in the Chinese economy. ${ }^{29}$ Moreover, some of the key earlier privatizations in developing countries' natural resource sector have been reversed either indirectly, as in Russia's renationalization of Yukos following inflated tax charges levied against the company, or directly, as in Argentina's outright expropriation of the controlling stake held by Spanish company Repsol in oil company YPF. In Brazil, privatizations often changed the form, but kept the substance, of government control. For instance, following privatization the federal government's majority stake in Brazilian mining giant Vale was replaced by a controlling coalition made of statecontrolled institutional investors and members of business groups tied by a shareholders' agreement. ${ }^{30}$

State ownership, in turn, can be both a product of, and a contributing factor to, the weak institutional environment in emerging markets. In laggard economies, capital market failures prevent the financing of large-scale projects by the private sector and hence prompt the state to assume an entrepreneurial function. ${ }^{31}$ Yet, once established, there is the risk that SOEs may crowd out, rather than crowd in, private sector firms.

State ownership may also help perpetuate low levels of legal investor protection through a more subtle mechanism: the political role of the state as a shareholder in corporate law reforms. In the 1990s, the Brazilian government, desirous of obtaining a larger control premium for itself in privatization sales, sponsored a series of statutory amendments explicitly aimed at eliminating various minority shareholder rights, to the

\footnotetext{
${ }^{27}$ The Company that Ruled the Waves, ECONOMIST, Dec. 17, 2011, at 109.

${ }^{28}$ Donald C. Clarke, Corporatisation, Not Privatisation, 7 CHINA ECON. REV. Quart. 27 (2003).

${ }^{29}$ Lin \& Milhaupt, supra note 25.

${ }^{30}$ Aldo Musacchio \& Sérgio G. Lazzarini, Leviathan in Business: Varieties of State Capitalism and their Implications for Economic Performance, at 16-17 (working paper, 2012), http://ssrn.com/abstract=2070942.

31 ALEXANDER GERSCHENKRON, ECONOMIC BACKWARDNESS IN HISTORICAL PERSPECTIVE (1962).
} 
detriment of outside investors. ${ }^{32}$ In China, the interests of the government as controlling shareholder have shaped the development of different areas of the law, from the structure of its first corporations' statute, to the availability of securities class actions and the doctrine of veil piercing. ${ }^{33}$

The government's sway over corporate governance in emerging markets far exceeds its direct influence as a controlling shareholder of large SOEs. In Brazil, the state has increasingly resorted to minority shareholdings - in the form of captive public pension funds and equity investments by its Development Bank (Banco Nacional de Desenvolvimento Econômico e Social - BNDES) - to shape corporate policy. ${ }^{34}$ These state-controlled actors exercise influence not only through their regular statutory voting rights in the shareholders' meetings, but also by explicit control-sharing arrangements as parties to shareholders agreements, which habitually grant the state-controlled institutional investors both board representation and veto rights over key corporate decisions. ${ }^{35}$ In China, the government's sway over, and support to, private sector corporations has effectively blurred the distinction between public and private modes of ownership. $^{36}$

Still another avenue for state intervention in corporate governance in emerging markets comes from the provision of subsidized debt financing to selected private firms. The loan volume extended by Brazil's BNDES alone has reached nearly four times that of the World Bank. ${ }^{37}$ Development economists have also long attributed the rapid catchup process in Asia to the export requirements inserted in governmental loan agreements to business groups. ${ }^{38}$ The Korean government has never been a major shareholder in Korean chaebols, but was nevertheless able to direct industrial policy through its grip

\footnotetext{
${ }^{32}$ Mariana Pargendler, State Ownership and Corporate Governance, 80 FORDHAM L. REV. 2917 (2012); Mariana Pargendler, The Unintended Consequences of State Ownership: The Brazilian Experience, 13 THEORETICAL. INQ. L. 503 (2012).

33 Donald C. Clarke, Corporate Governance in China: An Overview, 14 CHINA ECON. REV. 494, 495 (2003); Zhiwu Chen, Capital Markets and Legal Development: The China Case, 14 CHINA ECON. REV. 451, 453 (2003); Hui Huang, Piercing the Corporate Veil in China: Where Is It Now and Where Is It Heading?, 60 AM. J. COMP. L. 743 (2012).

${ }^{34}$ Musacchio \& Lazzarini, supra note 30.

${ }^{35}$ Mariana Pargendler, Governing State Capitalism: The Case of Brazil (unpublished manuscript, 2014).

${ }^{36}$ Curtis Milhaupt \& Wentong Zheng, Beyond Ownerhsip: State Capitalism and the Chinese Firm (unpublished manuscript, 2013).

${ }^{37}$ Samantha Pearson, A Bank Too Big to Be Beautiful, F.T., Sept. 23, 2012.

38 ALICE H. AMSDEN, THE RISE OF “THE REST": CHALLENGES TO THE WEST FROM LATE-INDUSTRIALIZING ECONOMIES 148 et seq. (2001).
} 
on the financial sector. ${ }^{39}$

\section{Reform efforts}

Capital markets in BRIC countries underwent major developments in the last two decades. As depicted in Figure 1, these countries transitioned from having meager or virtually nonexistent stock markets in the early 1990s to boasting sizable market capitalizations in the mid-2000s, even if they faced a substantial retreat thereafter as underlying economic conditions worsened. At the height of the bubble in 2007, China and Brazil, together with the United States, placed as the top three IPO destinations worldwide. $^{40}$

Figure 1. Market capitalization by year as a percentage of $G D P^{41}$

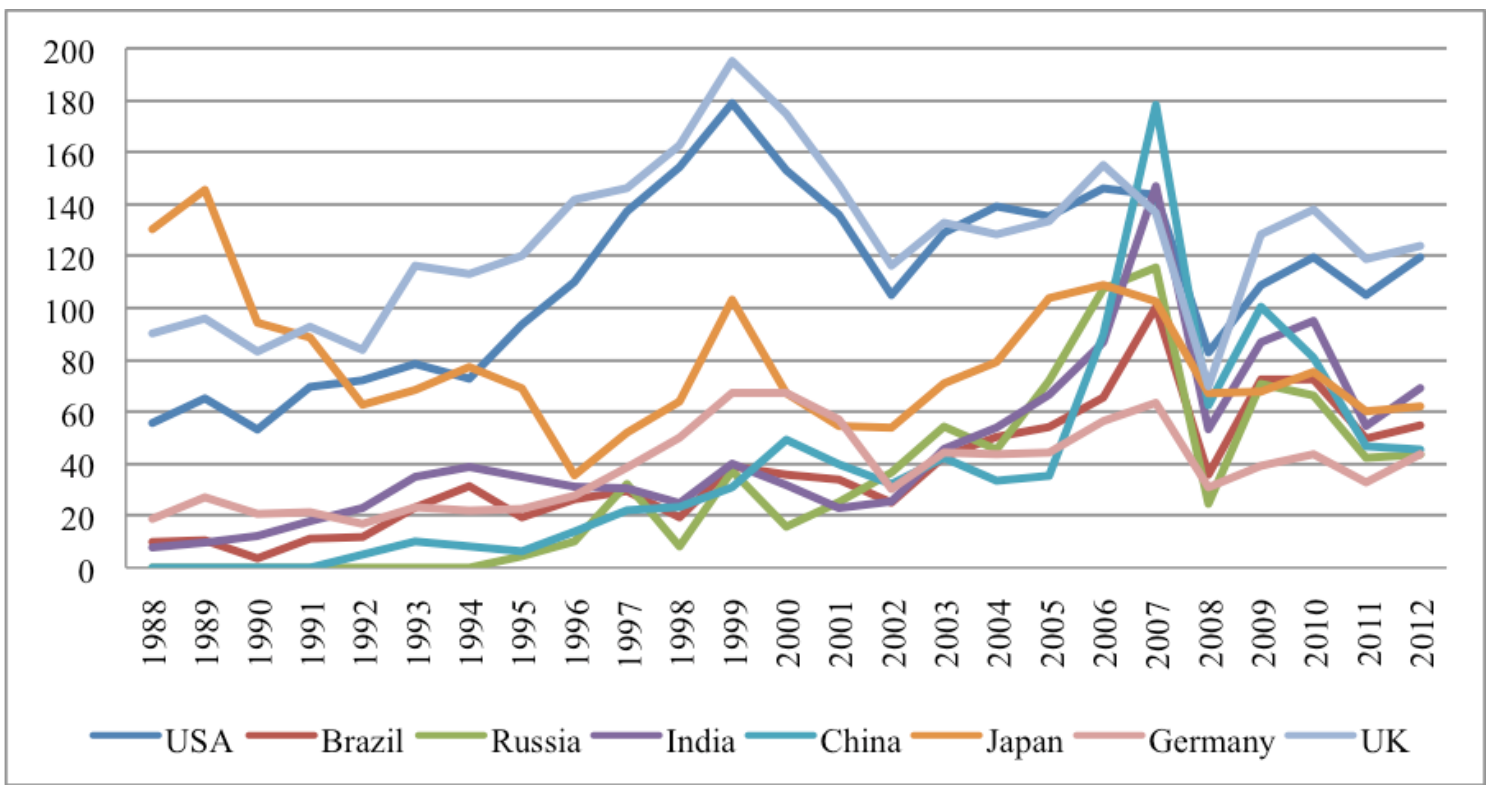

Nevertheless, the precise makeup of stock markets in emerging markets continues to vary widely. With only a few hundred listed companies (most of which of relatively large size), Brazil has struggled to induced medium-sized firms to access public markets. At the other end of the spectrum, India boasts the largest number of

\footnotetext{
${ }^{39}$ CURTIS J. MILHAUPT \& KATHARINA PISTOR, LAW AND CAPITALISM 118 (2008).

${ }^{40}$ Ernst \& Young, Growth During Economic Uncertainty: Global IPO Trends Report (2008).

41 Prepared by author based on World Bank data available at http://data.worldbank.org/indicator/CM.MKT.LCAP.GD.ZS.
} 
publicly-traded companies in the world. ${ }^{42}$ Whereas most Latin American countries exhibit low ratios of market capitalizations to GDP, Chile stands out as an exception, displaying ratios comparable to the robust equity markets of the United States and the United Kingdom in recent years.

The expansion of equity markets in emerging economies paralleled both economic and legal reforms. On the economic side, full and partial privatizations induced the private sector to assume the role of entrepreneur and financier that had been relinquished by the state. The elimination of barriers to trade and financial flows, in turn, encouraged foreign investors to jump in. On the legal side, the BRICs witnessed both the implementation of legal reforms and the adoption of superior corporate governance practices on a voluntary basis, with varying degrees of success.

\section{A. The tortuous path of legislative change}

Russia's experience is emblematic of the challenges inherent to large-scale reform. In the 1990s prominent U.S. legal scholars conceived its new corporate statute, which was deliberately based on a model of "self-enforcing" corporate law designed to compensate for the country's otherwise fragile legal system. ${ }^{43}$ Nevertheless, the good intentions and the attentiveness to local circumstances were insufficient to make the new law effective, as it notoriously failed to constrain subsequent instances of selfdealing. ${ }^{44}$

Adopted in 1994 as the legal framework for China's corporatization strategy, its Company Law mixed standard Western elements with local idiosyncrasies. Molded by the vision of a state-dominated economy, the Chinese corporate statute imposed a rigid mandatory framework that, while arguably suitable for SOEs, was woefully inadequate for private sector enterprise. ${ }^{45}$ The law was also reticent on the fiduciary duties of corporate managers and the means of enforcement, with no provision for derivative suits. $^{46}$

\footnotetext{
42 PAC-PME, Sumário das Propostas do Brasil + Competitivo, sl. 31 (Oct. 2013), available at http://www.pacpme.com.br/pacpme/web/default_pti.asp?idioma=0\&conta=45.

43 Bernard Black \& Reinier Kraakman, A Self-Enforcing Model of Corporate Law, 109 HARV. L. REV. 1911 (1996).

${ }^{44}$ Black et al., supra note 4.

${ }^{45}$ Clarke, supra note 33.

${ }^{46}$ Id. at 502.
} 
In 2005, China's corporations and securities statutes underwent a major overhaul that was strongly acclaimed by local scholars as an improvement to the existing statute that changed it "almost beyond recognition." 47 The new regime imposed fiduciary duties on managers and controlling shareholders, required listed firms to have independent directors, permitted derivative suits, and recommended (though it did not compel) cumulative voting in director elections. ${ }^{48}$ Nevertheless, a gap remains between the "law in the books" and the "law in action." For instance, the prominence role of the state has prompted a double standard in terms of legal enforcement, with SOEs appearing to face more lenient regulatory scrutiny than private sector firms. ${ }^{49}$

Brazil's 1976 Corporations Law - an innovative statute that borrowed freely from U.S. and European systems to address local challenges - remains largely untouched, as subsequent legal reforms turned out to be modest in scope. A 1997 amendment to the statute eliminated the requirement of a mandatory bid for minority shares in sale-of-control transactions with the purpose of allowing the state to appropriate the entire premium control to itself in privatization sales. These legal changes - which applied to firms under both state and private control - facilitated a series of abusive going-private transactions, thereby destroying investor confidence in Brazil's capital markets. After the bulk of privatization sales, a legal reform in 2001 reinstated some of the minority protections that had been previously abrogated, but was otherwise timid, as political opposition from controlling shareholders frustrated attempts at more transformational change. ${ }^{50}$

Major legislative change was also slow to come by in India. Subject to several amendments primarily designed to relax governmental controls and increase governance flexibility, India's Companies Act of 1956 remained in force until the significant overhaul by the Companies Bill of 2013. Some of the changes introduced by the new

\footnotetext{
${ }^{47}$ Xin Tang, Protecting minority shareholders in China: A task for both legislation and enforcement 143, in TRANSFORMING CORPORATE GOVERnANCE IN EAST ASIA (Hideki Kanda, Kon-Sik Kim \& Curtis J. Milhaupt eds., 2008).

${ }^{48} I d$.

49 Henk Berkman, Rebel A. Cole \& Lawrence J. Fu, Political Connections and Minority-Shareholder Protection: Evidence from Securities-Market Regulation in China, 45 J. FIN. \& QUANT. ANAL. 1391 (2011); William T. Allen \& Han Shen, Assessing China's Top-Down Securities Markets 8 (N.Y. Univ. Sch. of Law, Pub. Law \& Legal Theory Research Paper Series, Working Paper No. 10-70, 2010), http://papers.ssrn.com/sol3/papers.cfm?abstract_id=1648336.

${ }^{50}$ Ronald J. Gilson, Henry Hansmann \& Mariana Pargendler, Regulatory Dualism as a Development Strategy: Corporate Reform in Brazil, the United States, and the European Union, 63 STAN. L. REV. 475 (2013).
} 
statute were designed to incorporate U.S.-inspired mechanisms (such as class actions) into Indian law, while others clearly surpassed prevailing international standards, as in the new requirement of a maximum term limit of ten years for independent directors. ${ }^{51}$

\section{B. The role of government and private regulation}

Most of the progress in Brazil's corporate governance practices did not stem from sweeping statutory changes, but rather from a combination of private regulation and the increasingly activist stance by the Securities Commission (Comissão de Valores Mobiliários - CVM). Brazil's experience with the Novo Mercado - a premium voluntary listing segment of the São Paulo Stock Exchange (BM\&FBovespa) - was instrumental in the revitalization of the country's equity markets in the 2000s. By leaving the existing legal regime intact, this strategy of "regulatory dualism" successfully circumvented the powerful political opposition to reforms by existing corporate elites. ${ }^{52}$ Firms opting for a Novo Mercado listing are subject to strictures such as a ban on nonvoting shares, a mandatory bid rule in sales of control, and director independence requirements.

Modeled after the U.S. Securities and Exchange Commission, CVM was established in the 1970s as the sheriff of Brazil's capital markets. Subsequent statutory amendments in 1997 and 2001 increased its autonomy vis-à-vis the executive and expanded the scope of its regulatory oversight and disciplinary authority. Since capital markets boomed following a series of IPOs on the Novo Mercado, CVM has advanced the investor protection agenda in various fronts. ${ }^{53}$

First, the Commission made progress with respect to enforcement, culminating, for instance, in Brazil's celebrated first criminal conviction for insider trading in $2011 .^{54}$ Second, CVM came to embrace more protectionist interpretations of existing law, as in the famous Tractebel decision. By preventing controlling shareholders from voting to approve interested transactions, the Commission's new interpretation effectively

\footnotetext{
51 Akshaya Kamalnath, Corporate Governance Reform in India: Accommodating Local Culture along with the Drive for Global Convergence (working paper, 2013), available at http://ssrn.com/abstract=2382595.

${ }^{5} \mathrm{Id}$.

${ }^{53}$ For an overview of the enforcement authority of CVM and its recent developments, see Maria Helena Santana, Brazil: The Corporate Governance Framework and Practices relating to Supervision and Enforcement, in SUPERVISION AND ENFORCEMENT IN CORPORATE GOVERNANCE (OECD, 2013).

${ }^{54}$ Admittedly, given the lax treatment of white-collar crimes under Brazilian law, the convictions resulted in no jail sentences; defendants were sanctioned to mandatory community service, a monetary fine, and a temporary ban from serving as executives of publicly-traded companies.
} 
implemented a "majority-of-the-minority" approval requirement at shareholders' meetings. Third, CVM improved the existing regulatory landscape through a variety of channels: it published a series of stringent advisory opinions on matters ranging from fiduciary duties to the scope of antitakeover defenses, instituted more expansive disclosure regulations that are stricter than the original Novo Mercado standards, and innovated in permitting proxy access (or conferring reimbursement of expenses incurred in proxy solicitations) to shareholders holding more than $0,5 \%$ of the company's stock. And, finally, CVM has effectively exercised its statutory authority to punish illegal actions by company managers, as exemplified by the imposition of fines to the CFO and directors of listed firm Sadia. The Commission concluded that their failure to abide by the company's risk own management policies with respect to exchange rate derivatives, which resulted in hefty financial losses following the 2008 financial crisis, constituted a violation of their fiduciary duty of care under Brazilian law.

Similarly, until very recently corporate governance reform in India proceeded more quickly via the regulatory agency than the legislature. ${ }^{55}$ Established and strengthened as an oversight body between 1988 and 1992, the Securities and Exchange Board of India (SEBI) provided the regulatory framework for the country's expanding capital markets. Like CVM, SEBI's aggressive posture has at times led to accusations that it was overstepping its regulatory authority. ${ }^{56}$

Among the innovations embraced by SEBI is the watershed "Clause 49" of stock exchange listing agreements. First enacted in 2001 and revised in 2005, Clause 49 reflects a set of corporate governance standards following the voluntary Corporate Governance Code sponsored by the Confederation of Indian Industry (CII) - which, in contrast to the business establishment in Brazil, played a prominent role in sponsoring, rather than opposing, corporate governance reforms. The requirements described in Clause 49, which came to apply to all listed firms in India, ranged from a minimum percentage of independent directors to the institution of an audit committee and the requisite of chief executive certification of financial statements. Empirical studies documented a positive stock market reaction to the announcement of Clause 49 , as well

\footnotetext{
${ }^{55}$ John Armour \& Pryia Lele, Law, Finance, and Politics: The Case of India, 43 LAW \& SOC'Y REV. 491, 501 (2009).

${ }^{56}$ Afra Afsharipour, Corporate Governance Convergence: Lessons from the Indian Experience, 29 Nw. J. INT'L L. \& BUS. 335, 376 (2009).
} 
as a positive effect of stricter enforcement of these standards on firm value, ${ }^{57}$ even though actual compliance remained far from universal. ${ }^{58}$

\section{The role of courts}

Courts have generally played at best a modest and at worst a positively detrimental role in the transformation of corporate governance in emerging markets. The disadvantages of relying on the judiciary for investor protection include unreasonable delays, lack of technical sophistication, and even outright corruption. In most emerging market economies, corporate and securities litigation is a comparatively less significant means to rein in abuses by managers and controlling shareholders compared to more developed economies, and especially the United States.

There is a paucity of derivative lawsuits involving public company shareholders in both Brazil and India, even though these jurisdictions experience distinctively high levels of litigiousness in other areas of law. ${ }^{59}$ China's more recent recognition of derivative actions "on the books" did little to encourage their filing. ${ }^{60}$ Corporate litigation was also virtually nonexistent in South Korea before the East Asian crisis of the late 1990s (with actual derivative lawsuits being unheard of until 1997), but it has since soared. ${ }^{61}$ At another extreme, Russia's highly dysfunctional judicial system allows for the filing of lawsuits that are frivolous - but potentially successful, considering the specter of corruption - to be used as a takeover strategy. ${ }^{62}$

Resistance to legal change is still another issue plaguing courts' role in emerging markets governance. In both Brazil and India the judiciary has been receptive to the use

\footnotetext{
${ }^{57}$ Bernard S. Black \& Vikramaditya S. Khanna, Can Corporate Governance Reforms Increase Firm Market Values? Event Study Evidence from India, 4 J. EMP. LEGAL STUD. 749 (2007); Dhammika Dharmapala \& Vikramaditya Khanna, Corporate Governance, Enforcement, and Firm Value: Evidence from India, University of Michigan Law \& Economics Olin Working Paper No. 08-005 (2008).

${ }^{58}$ Kamalnath, supra note 51 , at 7.

59 Vikramaditya Khanna \& Umakanth Varottil, The Rarity of Derivative Actions in India: Reasons and Consequences, in THE DERIVATIVE ACTION IN ASIA: A COMPARATIVE AND FUNCTIONAL APPROACH 369 et seq. (Dan W. Puchniak, Harald Baum \& Michael Ewing-Chow eds., 2012); Gilson et al., supra note 52, at 494.

${ }^{60}$ See Donald C. Clarke \& Nicholas H. Howson, Pathway to Minority Shareholder Protection: Derivative Actions in the People's Republic of China 40 (Sept. 30, 2010) (unpublished manuscript) (on file with author).

61 Kon-Sik Kim, The Role of Judges in Corporate Governance: The Korean Experience, in TRANSFORMING CORPORATE GOVERNANCE IN EAST ASIA, 104 (Hideki Kanda, Kon-Sik Kim \& Curtis J. Milhaupt eds., 2008).

${ }^{62}$ Alexander Settles, Evolving Corruption: Hostile Takeovers, Corporate Raiding, and Company Capture in RUSSIA, CENTER FOR INTERNATIONAL PRIVATE ENTERPRISE (Aug. 31, 2009), http://www.cipe.org/publications/detail/evolving-corruption-hostile-takeovers-corporate-raiding-andcompany-capture.
} 
of constitutional law arguments to thwart reform efforts. In an attempt to cure the deficiencies of Brazilian laws on executive compensation disclosure, CVM issued new regulations in 2009 requiring companies to reveal the aggregate amounts paid to executives, as well as the highest and lowest salaries of directors and officers. Executives have so far successfully challenged the rule by contending that - in view of the privacy rights guaranteed by the Brazilian constitution and the country's particularly high levels of violence - CVM rules were unconstitutional as a violation of their fundamental rights to privacy and personal security.

In India, too, several constitutional challenges to new laws on insolvency and secured credit have delayed the implementation of important reforms for the development of India's credit market. ${ }^{63}$ A 2002 legal attempt to circumvent India's notoriously slow courts by creating a separate judicial body to enforce the provisions of the Companies Act was likewise frustrated by constitutional challenges. ${ }^{64}$ The Korean judiciary, in turn, has unduly oscillated between formalistic and liberal methods of statutory interpretation in reaching conservative opinions that favored the interests of chaebols over those of outside shareholders. ${ }^{65}$

The few exceptional instances of judicial innovation in corporate law prove the rule. Despite their notorious subordination to the Communist Party's wishes, Chinese courts played a surprisingly activist part in imposing American-style fiduciary duties notwithstanding the lack of explicit statutory provision under the 1994 Corporations Law. ${ }^{66}$ In recent years, Brazilian courts have come to consistently grant minority shareholders' requests for partial dissolution of closely-held corporations, even though such a remedy is not available under the Corporations Law. One might be tempted to interprete this newly recognized right as a creative solution to protect minority shareholders from abuse in situations where they would otherwise be unable to prove the existence of wrongdoing by controlling shareholders and managers. ${ }^{67}$ Such

\footnotetext{
${ }^{63}$ Armour \& Lele, supra note 55, at 506.

${ }^{64}$ Afsharipour, supra note 56, at 397.

65 Kon-Sik Kim, The Role of Judges in Corporate Governance: The Korean Experience, in TRANSFORMING CORPORATE GOVERNANCE IN EAST ASIA 104 (Hideki Kanda, Kon-Sik Kim \& Curtis J. Milhaupt eds., 2008).

${ }^{66}$ Nicholas Calcina Howson, The doctrine that dared not speak its name: Anglo-American fiduciary duties in China's 2005 company law and case law intimations of prior convergence, in TRANSFORMING CORPORATE GOVERNANCE IN EAST ASIA (Hideki Kanda, Kon-Sik Kim \& Curtis J. Milhaupt eds., 2008).

${ }^{67}$ On the practical difficulties of proving corporate wrongdoing in Brazil, see Érica Gorga \& Michael Halberstam, Litigation Discovery and Corporate Governance: The Missing Story About the "Genius of American Corporate Law" (working paper, 2013), available at http://ssrn.com/abstract=2239322.
} 
innovation, however, is not without costs, for it carries the risk of undermining the company's ability to "lock in" capital, a distinguishing - and economically crucial feature of the corporate form. ${ }^{68}$

\section{Alternative institutional arrangements}

Substitute mechanisms compensate for the difficulties in judicial enforcement. Given the substantive and procedural legal hurdles to derivative actions in Brazil and India, aggrieved shareholders have typically turned to the securities regulator instead CVM or SEBI - for more expedient and effective redress. ${ }^{69}$ In some countries - such as Chile, Brazil and, to some extent, China - listed firms have often attempted to circumvent the judicial route altogether by embracing arbitration as the preferred method of dispute resolution. ${ }^{70}$

Whereas in Italy and the United States public company arbitration is either outlawed or frowned upon as a scheme for potential investor abuse, in emerging markets arbitration may operate as a second-best solution given the deficiencies of the court system. ${ }^{71}$ Novo Mercado, the premium corporate governance segment of the São Paulo Stock Exchange (BM\&FBovespa), in fact mandates the arbitration of all internal affairs and securities law disputes, operating on the assumption that this is the most investor-friendly method of resolving corporate conflicts. Nevertheless, the choice for arbitration is not without challenges, especially where, as in Brazil, its proceedings are confidential, thus hindering the development of case law and contributing to the opaqueness of the institutional environment.

At any rate, changes in formal statutes, regulations and enforcement at the national level are insufficient to account for the extent of the transformation in emerging markets' corporate governance practices. Brazil's positive experience with the Novo Mercado illustrates that self-regulation through stock exchange listing requirements may play a crucial role in kick-starting much-needed reform. Scholars have argued that,

\footnotetext{
${ }^{68}$ Lynn Stout, On the Nature of Corporations, 2005 U. ILL. L. REV. 256 (for a an articulation of the concept of capital lock in); Edward B. Rock \& Michael L. Wachter, Waiting for the Omelet to Set: Match-Specific Assets and Minority Oppression in the Close Corporation, 24 J. CORP. L. 913 (1999) (describing the economic benefits of capital lock in).

69 Khanna \& Varottil, supra note 59, at 389 (India); Paulo Cezar Aragão, A CVM em Juízo: Limites e Possibilidades, 34 REVISTA DE DiREITO BANCÁRIO E DO MERCADO DE CAPITAIS 38, 42 (2006).

${ }^{70}$ Christos A. Ravanides, Arbitration Clauses in Public Company Charters: An Expansion of the ADR Elysian Fields or a Descent Into Hades?, 18 AM. REV. INT'L. ARB. 371 (2007).

${ }^{71}$ Id.
} 
in China, reputational sanctions through public criticism by the Shanghai and Shenzen stock exchanges help deter corporate wrongdoing in the absence of formal public enforcement. ${ }^{72}$ Individual emerging market companies are also free to adopt sensible corporate governance practices, which empirical studies have found to be associated with improvements in firm performance. ${ }^{73}$

Finally, international (and especially U.S.) cross-listings by emerging market corporations have been another engine of corporate governance change. Existing literature has posited two different theories to explain firms' decisions to list their shares on a foreign exchange. According to the market segmentation (and liquidity) hypothesis, the benefits of cross-listings lie in permitting foreign issuers to expand and diversify their investment base. Proponents of the competing bonding hypothesis, by contrast, interpret oversea listings as a mechanism by which firms can make a credible commitment to the higher standards of corporate governance and transparency prevailing in the host jurisdiction. ${ }^{74}$ But whether or not bonding considerations are determinative, overseas listings certainly play a role in corporate governance convergence.

\section{Convergence and persistence in emerging markets governance}

If the recent transformation of corporate governance practices in emerging markets is evident, the extent and direction of change remains contested. A main theme of the academic literature in the last decades concerns the impact of globalization on corporate structures and practices. Specifically, the question is whether corporate governance systems around the world have become increasingly uniform (the "convergence thesis"), or if, instead, path dependence significantly constrained the course of subsequent developments (the "persistence thesis"). ${ }^{75}$ While this debate

\footnotetext{
${ }^{72}$ Benjamin L. Liebman \& Curtis J. Milhaupt, Reputational Sanctions in China's Securities Market, 108 COLUM. L. REV. 929 (2008).

${ }^{73}$ See Claessens \& Yurtoglu, supra note 13.

${ }^{74}$ See, for a review of this literature, G. Andrew Karolyi, Corporate Governance, Agency Problems and International Cross-Listings: A Defense of the Bonding Hypothesis, 13 EMERGING MKTS. REV. 516 (2012).

75 For a collection of prominent works on this theme, see CONVERGENCE AND PERSISTENCE IN CORPORATE GOVERNANCE (Jeffrey N. Gordon \& Mark J. Roe eds., 2004).
} 
focused primarily on the usual mature economies, it is easily replicated with respect to emerging markets. ${ }^{76}$

On the one hand, rising globalization, foreign competition, and international investment flows all militate in favor of some form of convergence. Mounting competitive pressures increase domestic firms' need for outside financing, which, in turn, creates demand for stronger forms of investor protection. As foreign investors flock into emerging market economies, they bring with them the corporate governance practices, structures, and norms of their home country, even if not always with due regard to local specificities.

On the other hand, the theoretical arguments favoring persistence in corporate governance structures are also strong. The political economy of corporate lawmaking is tilted toward existing structures, as controlling shareholders, dispersed investors, managers, and workers engage in lobbying efforts to maintain their status and privileges. And, perhaps more importantly, there are significant institutional complementarities between the corporate governance regime and other political and economic dimensions, such as the form of industrial organization, the flexibility of labor markets, the characteristics of the educational system, and the structure of political representation, which, taken together, engender different "varieties of capitalism.", As a result, particular corporate governance systems may be less amenable to change than a closer focus on corporate dimensions alone would suggest.

\section{A. Forms, functions, and idiosyncrasies}

The corporate structure has long become universal. Irrespective of their origin, corporations around the world today share certain core attributes, such as legal personality, tradable shares, limited liability, delegated management, and investor ownership. ${ }^{78}$ These features, in turn, are increasingly relevant in emerging markets, as state-owned enterprises previously operating as governmental divisions in countries such as China and Russia, among many others, came to adopt the corporate form. But

\footnotetext{
${ }^{76}$ See, e.g., Henry Hansmann \& Reinier Kraakman, Convergence of Corporate Governance: Promise and Prospects, in CONVERGENCE of Corporate Governance: Promise AND Prospects (Abdul Rasheed and Toru Yoshikawa eds. 2012).

${ }^{77}$ See Mark J. Roe, Rents and their Corporate Consequences, 53 STAN. L. REV. 1463 (2001); VARIETIES of CAPITALISM: THE InSTITUTIONAL FOUNDATIONS OF COMPARATIVE ADVANTAGE (Peter Hall \& David Soskice eds., 2001).

${ }^{78}$ John Armour, Henry Hansmann \& Reinier Kraakman, What is Corporate Law?, in THE ANATOMY OF CORPORATE LAW: A COMPARATIVE AND FUNCTIONAL APPROACH 1 (Reinier Krakman et al., 2009).
} 
beyond the spread of corporate organization itself, there has been a visible tendency toward the implementation of the wide array of corporate law and governance features prevailing in developed, and especially Anglo-Saxon, markets - ranging from independent directors and fiduciary duties to insider trading bans and securities agency enforcement - to emerging market economies. Still, the intensity of such convergence, as well as the precise mix of best practices, can vary dramatically from one jurisdiction to another.

Focusing only on the adoption of identical corporate governance practices prevailing in developed countries will certainly understate the degree of actual convergence. Functional, rather than formal, convergence is often the norm. ${ }^{79}$ Diverse arrangements such as public company arbitration, stiff reputational sanctions, and governmental oversight of firm performance all operate as institutional substitutes that further the goal of investor protection without conforming to international "best practices."

Yet it would be both naïve and misguided to overstate the convergence thesis in its strong form. Just as functional convergence is feasible without accompanying formal convergence, the reverse is also true, as formally identical practices can have disparate significance in different underlying environments. Scholars have duly admonished against the "elusive quest" for universal corporate governance standards, recognizing that identical practices can have diverse consequences depending on the prevailing ownership structures. ${ }^{80}$

Take, for instance, a longstanding policy prescription of the U.S. corporate governance movement: the separation of the roles of board chair and CEO. By providing the board with independent leadership, the split of roles is designed to ensure that directors are in a position to effectively monitor the company's management. However, despite major strides, this recommendation remains highly contested in the U.S. context of powerful CEOs, as independent chairs are still far from universal. In Brazil, where political opposition to corporate governance changes is particularly fierce, companies have refrained from vetoing the inclusion of a mandatory split of positions as

\footnotetext{
${ }^{79}$ See Ronald J. Gilson, Globalizing Corporate Governance: Convergence of Form or Function, 49 AM. J. COMP. L. 329 (2001).

${ }^{80}$ Lucian A. Bebchuk \& Assaf Hamdani, The Elusive Quest for Global Governance Standards, 157 U. PA. L. REV. 1263-1317 (2009).
} 
a listing requirement for all premium corporate governance listing segments on the BM\&FBovespa.

The greater receptivity to independent board leadership by Brazilian firms is less due to their especially strong commitment to best practices of corporate governance than to its different contextual significance. In a system of highly concentrated corporate control, the primary source of agency costs is not managerial omnipotence but rather the potential of abuse by controlling shareholders. While controlling shareholders typically seek to keep management in a tight leash, they do not always covet the consuming office of chief executive. And, even when they do, having an independent board chair may not be exactly threatening when she is elected by the controlling shareholder himself. In fact, a substantial number of Brazilian companies already had a split in place - with the controlling shareholder serving as board chair and delegating everyday managerial decisions to a professional CEO - before the advent of the listing requirement, which makes it far less consequential in the Brazilian context of concentrated ownership than in the U.S. system of dispersed ownership.

Similarly, while the United States has only recently embraced an advisory shareholder vote on executive compensation ("say on pay") at least every three years, Brazilian corporate law have long required shareholders to approve executives' overall pay packages on an annual basis. In a context of concentrated ownership, however, the rule has different implications: it provides controlling shareholders with yet another opportunity to supervise management as well as to approve their own salaries as board members. In some Brazilian firms, director compensation to members of the controlling family even exceeds the pay of the professional CEO.

As a general matter, the recent transformation in emerging markets' governance has combined the influence of prevailing practices in mature markets with indigenously designed improvements. More recently, the origins of institutional transplants from foreign sources have also begun to change. Rather than invariably looking to developed countries for model norms and practices, emerging market economies have increasingly learned from each other's experiences. The apparent success of Brazil's Novo Mercado has invited similar initiatives in India and the Philippines. ${ }^{81}$ After taking over traditional

\footnotetext{
${ }^{81}$ Inspiration from the East: Encouraged by the Novo Mercado's Success, the Philippines and India Create Special Listing Tiers in Their Own Stock Exchanges, 72 CAPITAL ABERTO (Aug. 2009).
} 
U.S. firms such as Heinz and Burger King, Brazil's 3G Capital fund has exported its ruthless efficiency-oriented management style. In the future, one can expect the crossfertilization in corporate to become ever more multidirectional, with mature economies receiving the influence of emerging markets' norms and practices - not least due to the rising levels of foreign direct investment by multinationals and national champions from China, India, Brazil, and the like.

\section{B. Evolving ownership structures}

Changes in ownership structures have proceeded at a somewhat slower pace. Given the continued predominance of concentrated ownership in the BRICs, hostile takeovers either remain exceedingly rare, or assume a very different meaning. In Russia, a "hostile takeover" is not, as one might expect, the acquisition of a controlling stake from public shareholders against managers' will - a strategy which is hardly feasible given the presence of a controlling shareholder in most companies. Instead, it refers to the relatively common, if extreme, practice of gaining control over a firm through dubious practices ranging from fraud and corrupt law enforcement to outright violence. $^{82}$

In Brazil, the failure of the hostile bid by meat processing firm Sadia for its chief competitor Perdigão - the first and only hostile takeover attempt in recent history illustrates how the apparent increase in ownership dispersion in recent years may be illusory. ${ }^{83}$ Despite the absence of a single controlling shareholder, the target's several blockholders were party to a shareholders' agreement, and acted swiftly to reject the offer notwithstanding its sizable premium. Even in India, where a non-trivial minority of firms is widely held, hostile takeovers have faced practical difficulties thanks to hefty regulatory hurdles to control changes as well as the presence of founder-friendly financial institutions. Past hostile bids have failed for reasons ranging from the outright refusal of the target companies to register the acquired shares to strong political opposition leading to the enactment of regulatory impediments. ${ }^{84}$ A notable exception is

\footnotetext{
${ }^{82}$ Settles, supra note 62.

${ }^{83}$ For a description of the recent evolution of ownership structures in Brazil, see Érica Gorga, Changing the Paradigm of Stock Ownership from Concentrated Towards Dispersed Ownership? Evidence from Brazil and Consequences for Emerging Countries, 29 NW. J. INT'L L. \& BUS. 439 (2008).

${ }^{84}$ Armour \& Lele, supra note 55, at 506.
} 
Korea, where reforms following the Asian crisis left local firms vulnerable to foreign threats. ${ }^{85}$

When it comes to ownership structures, convergence came mostly from the opposite direction: while dispersed ownership remains rare in emerging markets, there has been a visible trend toward concentrated corporate control in the United States. Dual-class shares, once banned by the New York Stock Exchange (NYSE) listing standards until 1984, used to be commonplace only in the South and continental Europe. In the 2000s, however, they experienced a revival in the U.S. market, as founders of highly prominent technology firms, such as Google and Facebook, resorted to multiple voting shares to lock in control of the company before going public. ${ }^{86}$ And, ironically, the U.S. market might become a refuge for foreign firms seeking entrenched management structures. In 2013, Chinese internet giant Alibaba announced that it would pursue a NYSE listing after the Hong Kong Stock Exchange - its initially preferred venue - refused to exempt it from the listing rules prohibiting dual-class stocks.

\section{Stakeholders and corporate governance}

Through the effect of concentrated ownership structures and accompanying legal institutions, the interests of (controlling) shareholders often take center stage in emerging market firms. ${ }^{87}$ Yet - at least on the books - consideration of stakeholder interests is also particularly salient in their governance. Even though the spurt in economic growth in the 2000s ameliorated social conditions for many, poverty and inequality - not to mention human rights violations - remain a major challenge in emerging market economies. ${ }^{88}$ In this context, issues of distribution assume particular significance in shaping different doctrines of corporate law.

\footnotetext{
${ }^{85}$ Hwa-Jin Kim, A Tale of Three Companies: The Emerging Market for Corporate Control in Korea, in TRANSFORMING CORPORATE GOVERNANCE IN EAST ASIA, 122 (Hideki Kanda, Kon-Sik Kim \& Curtis J. Milhaupt eds., 2008).

${ }^{86}$ See Joseph A. McCahery \& Erik P.M. Vermeulen, Six Components of Corporate Governance That Cannot Be Ignored, ECGI Working Paper No. 248 (2014) (regarding the reemergence of dual-class firms in the United States as consistent with long-term value creation).

${ }^{87}$ In Brazil, for instance, there is widespread use of shareholder agreements that legally bind the votes of corporate directors, to the despair of corporate governance advocates. Érica Gorga, Corporate Control \& Governance after a Decade from "Novo Mercado": Changes in Ownership Structures and Shareholder Power in Brazil (unpublished working paper, 2013) (on file with author).

${ }^{88}$ Although absolute poverty has decreased in the last decades, emerging markets (with the notable exception of Brazil) have witnessed a concominant increase in income inequality.
} 
In assessing the distributive effects of corporate governance policies, the degree of equity ownership by the general population plays a fundamental role. In a "society of shareholders," the norm of shareholder primacy assumes greater legitimacy compared to contexts in which only a small fraction of the citizenry has a direct stake in stock market outcomes $^{89}$ - as is generally the case in emerging markets, where the recent capital market boom was mostly fueled by foreign investors. While on average $40 \%$ of the population in developed countries is invested in stock markets, the proportion falls to $5 \%$ in emerging economies (ranging, in turn, from a minuscule $0.3 \%$ in Brazil to approximately $10 \%$ in China)..$^{90}$

Consequently, in an environment where stockholders are few and far between (and mostly well-off to begin with), the conflict between the interests of shareholders and nonshareholder constituencies assumes special significance. And, distributional concerns aside, the norm of shareholder primacy might also fail to generate efficient outcomes if product markets are uncompetitive, ${ }^{91}$ a still common feature of developing countries.

Perhaps unsurprisingly, emerging markets have not fully embraced the pursuit of shareholder value as the exclusive normative goal of corporate law. In the 1990s, when the corporate statute was silent on the content of fiduciary duties, the Chinese government clarified that SOEs should be managed towards the goal of "preserving and increasing the value of State assets," 92 an objective that is distinct from, and that can easily conflict with, the maximization of firm value. Under Brazil's corporations statute "the controlling shareholder must use its influence so as to make the company fulfill its purpose and its social function, and has duties and responsibilities to the other shareholders, employees and the community in which it operates, whose rights and interests he must loyally abide by and respect." ${ }^{93}$ The statutory concept of abuse by

\footnotetext{
${ }^{89}$ For data on stock ownership levels around the world, see Paul A. Grout, William L. Megginson \& Anna Zalewska, One Half-Billion Shareholders and Counting: Determinants of Individual Share Ownership around the World (working paper, 2009), available at http://ssrn.com/abstract=1457482.

${ }^{90}$ PAC-PME, supra note 42.

${ }^{91}$ For this argument, see Mark J. Roe, The Shareholder Wealth Maximization Norm and Industrial Organization, 149 U. PA. L. REV. 2063 (2001).

92 Xiaonian Xu \& Yan Wang, Ownership Structure, Corporate Governance and Corporate Performance: The Case of Chinese Stock Companies 7 et seq., World Bank Policy Research Working Paper 1794 (1997), at 5.

93 Art. 116, Lei No. 6.404, art. 26, de 15 de Dezembro de 1976, DiÁRIO OFICIAL DA UNIÃo [D.O.U.] de 17.12.1976 (Braz.).
} 
controlling shareholders is broad enough to explicitly encompass actions that harm not only the company or its minority shareholders, but also the "national economy."

Social concerns have impinged on other facets of corporate law as well. Brazil, for instance, has embraced particularly extensive version of veil piercing doctrine, thereby mitigating the attribute of limited shareholder liability in critical areas of law. Whenever the creditor is an employee or a consumer (as defined by consumer protection legislation), shareholders may be - and recurrently are - held liable whenever legal personality poses an obstacle to the discharge of the companies' obligations, despite the absence of fraud or other forms of abuse.

Rules addressing stakeholder interests also appear in Chinese corporate governance as well. The main such interests are, of course, those of the state as run by the Communist Party. But the formally communist regime also pays considerable lip service to workers.

China has implemented employee board representation since its first modern Company Law of 1994. The 2006 legal reforms gave the prior requirement teeth by fixing the minimum participation of workers at one-third of the supervisory board. ${ }^{94}$ The same statute provides that "[i]n the course of doing business, a company must comply with laws and administrative regulations, conform to social morality and business ethics, act in good faith, subject itself to the government and the public supervision, and undertake social responsibility." 95 Moreover, concerns about pay disparities and internal pay equity have led the Chinese government to cap executive compensation at 20 times average employee salary in all SOEs overseen by the StateOwned Asset Supervision and Administrative Commission of the State Council (SASAC), the governmental agency that serves as the controlling shareholder for China's largest SOEs. ${ }^{96}$

While instances of human rights abuses, environmental degradation and hazardous consumer products are still recurrent, China, at least on paper, has made formal progress when it comes to the embrace of Western-style corporate social

\footnotetext{
${ }^{94}$ Li-Wen Lin, Corporate Social Responsibility in China: Window Dressing or Structural Change, 28 BERKELEY J. INT'L L. 64 (2010).

95 Id. at 71 .

${ }^{96}$ Milhaupt \& Zheng, supra note 36, at 15 (noting that the widespread practice of "on duty consumption" of perquisites has nevertheless undermined the rule's efficacy).
} 
responsibility (CSR) with "Chinese characteristics." 97 Chinese stock exchanges have required listed companies to disclose their CSR policy. The State-Owned Asset Supervision and Administrative Commission of the State Council (SASAC) - the governmental agency that serves as the controlling shareholder for China's largest SOEs - has issued a Guide Opinion on CSR. ${ }^{98}$ While labor rights and environmental obligations figure prominently in the CSR movement in China, the promotion of human rights remains conspicuously absent. ${ }^{99}$

India's Companies Act of 2013 is particularly innovative in its approach to social considerations. Although reasonable minds may differ on its merits, the statute breaks new ground in requiring companies to spend at least two percent of average net profits to promote their corporate social responsibility policy, preferably in local areas, or to otherwise explain the reasons for noncompliance. It also seeks to promote women participation on corporate boards, albeit timidly, by conditioning the increase in the number of directors beyond fifteen to the presence of at least one female board member.

Yet emerging markets are not alone in the trend (however meritorious) of internalizing social issues in corporate governance. In the last decade, a number of European countries, such as Norway, France and Italy have mandated minimum quotas for female directors on boards. Under the U.K. Companies Act of 2006, directors are under a duty to promote the success of the company for the benefit of shareholders, but must pay due regard to other interests such as those of employees, customers, and the community. In the United States, too, social concerns have recently made a reappearance, even if mostly in the form of new disclosure requirements on subjects such as the consideration of diversity in director appointments, the pay gap between chief executives and their employees, and even in the use of "conflict minerals" from the Democratic Republic of the Congo.

\section{Conclusion}

Today's emerging markets comprise a historical category rooted in the early promise, and later success, in capital market development. The rapid stock market growth in the last decades was associated with deep a transformation in the underlying

\footnotetext{
97 Id. at 84 .

${ }^{98}$ Id. at 74 .

${ }^{99}$ Id. at 66.
} 
institutional infrastructure, even if not always through the adoption of the same mechanisms prevailing in developed markets. Instances of formal convergence to international (and especially U.S.) corporate governance best practices abound. The significance and practical consequences of these transplanted practices in this new context may, however, be quite different from what would be expected in their original environment. Critically, emerging markets governance is far uniform, and the degree of internal diversity might even increase in the future, as the great variation in their political, economic, and legal conditions will likely continue to impact the performance of their economies and stock markets going forward.

Finally, the very category of emerging markets itself is unlikely to remain stable over time. As the BRIC economies seemed to falter in the second decade of the twentyfirst century, new acronyms surfaced to describe then popular investment destinations. But irrespective of the precise mix of jurisdictions, attention to the corporate laws and governance structures in a broader array of jurisdictions beyond the traditional few of the Wealthy West is likely here to stay - to the great benefit of those interested in the role of legal institutions in shaping capitalism's different incarnations. 